\title{
Evaluating the performance of Kuwait International Bank "An analytical study of the effects of the convert from the conventional system to the Islamic system "
}

\author{
${ }^{1}$ Dr. Ahlam Al-thawi, ${ }^{2}$ Manal Al Rbaiaan \\ ${ }^{1}$ Head of the Department of Administrative Sciences, College of Administrative and Finance \\ sciences, Gulf University - Bahrain \\ ${ }^{2}$ Researcher, College of Administrative and Finance sciences, Gulf University - Bahrain
}

\begin{abstract}
This research aimed to recognize the extent of reflecting the application of Islamic banking system on the financial performance of banks. It's also helps to find the feasibility sought by the conventional banks by directing to converting to the Islamic system through evaluating the financial performance of the conventional banks before and after its shift; by using the financial indicators and the personal interviews that answered the main question of the research which is; Is there a difference in the bank's performance before and after the shift from the conventional system to Islamic system?

The most important research results were that the pre-preparation of the bank shift plan and the creation of its employees is one of the most important factors in the success of the process. Also the possibility of banks converting in the state of Kuwait is available and enacted with laws that regulate working therein. The financial ratios are also main indicators to identify the performance of the bank. The professional vision of the bank converting experience has also suggested the right decision to turn to the Islamic regime to achieve the desired end of all the technical aspects, including banking, financial and legal ones.
\end{abstract}

Keywords: Evaluating, performance, Islamic Banking, conventional Banking, Performance ratios, liquidity ratio, Equity Return Ratio

\section{Council for Innovative Research}

Peer Review Research Publishing System

\section{Journal: International Journal of Management \& Information Technology}

\author{
Vol. 8, No. 2 \\ editor@cirworld.com \\ www.cirworld.com, member.cirworld.com
}




\section{INTRODUCTION}

The emergence of Islamic banking system in the world has had an influential role in attracting a segment of the community, were in isolation from dealing with the existing banks operating according to the conventional banking system, due to its reservation on the conventional financial transactions. In recent days, the Islamic bank system has became the destination of most customers after confirming the feasibility and effectiveness of its performance compared with the conventional banking system in terms of the stability of the financial position and the ability to cope with financial crises, as demonstrated in the case of the global financial crisis in 2008, and the extent of the proportion of affected both systems there.

\section{RESEARCH METHODOLOGY}

\section{1-1 Research Problem}

The financial statements of the bank indicate that there are differences in the performance of the bank during the period of the two systems, and accordingly, the researcher has found that the research problem is represented in the bank's different performance before and after its shift between the conventional and Islamic systems, via comparing the bank's financial statements during the two periods and analyses its financial ratios. The general trend towards shift from the conventional to the Islamic bank system which became dominated by the banking sector is what has encouraged the researchers to choose the study of this subject, especially due to the progress effect of the global financial crisis in 2008 , bringing the trend as a reaction to hedge against the coming financial crises and the proof of this succession of experiments and transformation processes of banks and its continuity conventional banking system.

\section{1-2 Research questionnaire}

The research raises the main following quest:

1. Is there a difference in the bank's performance before and after the shift from the conventional banking system to Islamic banking system?

Having the following sub-questions:

1. Is there a difference in the performance of the liquidity of the bank after its shift to the Islamic system?

2. Is there a difference in the performance of the profitability of the bank after its shift to the Islamic system?

3. Is there a difference in the performance of the activity of the bank after its shift to the Islamic system?

4. Is there a difference in the performance of debt management for the bank after its shift to the Islamic system?

5. Is there a difference in the performance of a market for the bank after its shift to the Islamic system?

\section{1-3 Research Objectives}

The research aims to achieve the following:

Find the difference in the performance of the bank before and after the shift periods from the conventional system to the Islamic system, and compare the financial performance of the bank between the two periods using the method of financial ratios.

\section{1-4 The research importance}

The research importance is represented in finding the added-value; banks seek via the shift from the conventional system to the Islamic one and clarifying the positives of making decisions and its reflection on the efficiency and effectiveness of their performance, in addition to achieving their goals.

\section{1-5 Research Methodology}

The analytical descriptive research approach has been used in this research by describing the reality of the financial performance of the bank using the method of financial evaluation of financial ratios, and then analyzes this fact and comparing it to the bank during the periods before and after the transition between the two systems. In addition to relying on the statistical approach which is based on scientific reasoning based on the use of statistical measures (the mean, standard deviation and coefficient of variation), as well as the method of personal interview for the professional experts with competence in the banking, financial and forensic opinion art in their respective areas of specialization.

\section{THE THEORETICAL FRAMEWORK FOR THE SHIFT OF THE CONVENTIONAL BANKING TO THE ISLAMIC BANKING}

\subsection{The concept of Islamic banks and conventional banks}

I) the definition of Islamic banks: 
It is a financial institution which shall take the Islamic Sharia as a basis for the financial dealings, so as to play the role of the legitimate financial role between two customers' categories; savers and borrowers, so as to achieve the legitimate financial development solidarity to both.

- Islamic banks characteristics:

1. Dealing entirely with the provisions of the Islamic Sharia in all its dealings.

2. staying away from dealing with the beneficial banking and trading them.

3. Building on the principle of participation in profit and loss, and hence share in the risk.

4. Finding economic development in the community, which in turn ensures social development.

\section{II) The definition of conventional banks}

It is a financial institution that acts as a financial intermediary between segments of society to deal with money for the purpose of investment and achieving the profit from the difference between the interest rate paid to the capital owners and the interest rate derived from the projects and ideas owners.

- Characteristics of conventional banks: (Ola Sha'rani 2010, p 39)

1. The banking facilities shall be granted in return for expensive doubled- interests from the clients.

2. The period of most facilities is a year, any short-term financing to ensure the rapid return.

3. Focusing on devout senior customers to ensure the recovery of bank funds and benefits to achieve profits.

4. The obligation to provide guarantees, to be used as a pressure factor in the case of a stall or stumble from some customers.

\section{2-2 Shift from conventional banking to Islamic banking}

a. Shift from conventional banking to Islamic banking motives

1. Commitment to the pursuit of Islamic law and the application of its provisions on banking transactions.

2. Seeking to increase profitability, as a result of notable successes for Islamic banks.

3. The desire to direct investment rather than financial intermediation (lending and borrowing).

\section{2-3 Shift types}

\section{a. Partial shift}

The partial shift is represented in several types, represented by the researcher as follows;

a- The shift through the development of the bank's conventional banking services and formulas related to the banking sector to comply with the provisions of Islamic Sharia. (Said Almrtan 2005, p 436) quote.

b- The shift through establishing the conventional bank to the service providing windows and banking formulas, so as to be compatible with the provisions of Islamic Sharia . (Fahd Al-Sharif, 2005, p 13) quote.

c- The conventional bank shift to work with all banking transactions in accordance with the provisions of Islamic Sharia through specialized branches for it. (Said Almrtan 0.2005, p 435) Adapted and Qatar (Fahad Al-Sharif, 2005, p 13).

d- The shift through establishing conventional banks of new banks operating in all banking activities in accordance with the provisions of Islamic Sharia. (Ahmad travel 0.2004, p 207) quote.

\section{b. Total shift}

The total shift through replacing the compatible business with the provisions of Islamic Sharia at the place of the offense business via shifting the bank entirely in accordance with the provisions of the Islamic Sharia, and this form is one of the most credible forms of shifting, as it is based on moving away from the practice of any acts contrary to the provisions of Islamic Sharia. (D. Yazan Atiyat, 2007, p 52).

\section{THE SHIFT PROCESS OF KUWAIT REAL ESTATE BANK FROM A CONVENTIONAL BANK TO THE INTERNATIONAL BANK OF KUWAIT AS AN ISLAMIC BANK}

\section{3-1 shift plan:}

Through the two researchers' view on the cases of banks shift between two different systems, it is evident that The banking system shall shift from the existing system to a new system by passing a transition phase, in which the bank turns between the two systems. This is an application of a placed work plan for the transition process. 


\section{3-2 Kuwait Real Estate Bank's shift plan:}

Through the two researchers' queries from the officials in the bank, who cope with its shift phase and through previewing the bank's shift plan between the two systems, we shall here tackle the bank's shift plan by reviewing the process phases:

Phase I: Preparation of the shift plan in order to obtain the initial approval of the Central Bank of Kuwait.

This phase shall be deemed one of the basic and crucial phases in the bank's history as it is a phase stating the start of the bank's shift after getting the conditional initial approvals of the Central Bank of Kuwait.

Phase II: Preparing for the shift plan as a prelude to the shift process: it is a phase to prepare a comprehensive plan, taking into account all the shift requirements, either how to shift the existing work and how to liquidate it and also the possibilities that could arise from that, noting the steps and procedures in detail according to a specific schedule.

Phase III: The implementation phase: This phase is one of the most important stages in which rows shall be arranged and shall start implementation with the full capacity of the bank as it has a set of complementary and paralleled-application procedures which must stick to deadlines of all the working groups.

Phase IV: Filtering outstanding and non-ended phase: these phases shall deal with the shift secretions which need extended and tangled rebounds

(Shift process and completion, 2009, p. 99-100)

\section{COMPARING THE PERFORMANCE OF THE BANK IN THE APPLICATION OF THE TWO SYSTEM; CONVENTIONAL AND ISLAMIC}

In this topic, the two researchers has set the analytical financial analysis of comparative annual data for Kuwait International Bank for the period 2003 to 2011, using some of the most important financial ratios to measure and compare the performance of the bank's financial period of the two systems, accounting for annual data for the period from 2003 to 2006, the Bank's performance to the former system (conventional), The annual data for the period from 2008 to 2011 shall represent the Bank's performance for the new system (Islamic) as well as comparing the performance of Kuwait International Bank with the performance of other Islamic banks in the Kuwaiti banking sector during the period of shift to the new system.

Table (1) Performance ratios used in financial analysis in this study

\begin{tabular}{|c|c|c|}
\hline $\begin{array}{l}\text { Performance } \\
\text { ratios group }\end{array}$ & Performance ratios & Ratios law \\
\hline \multirow[t]{2}{*}{ Liquidity ratios } & Current Ratio & Current assets / current liabilities \\
\hline & Quick ratio & $\begin{array}{l}\text { (Cash + cash at the central bank + Cash at other } \\
\text { banks) / deposits) * } 100\end{array}$ \\
\hline \multirow[t]{4}{*}{ Profitability ratios } & Book Value Per Share & (Capital + reserves) / number of shares \\
\hline & Earnings per share & Net Profit / Number of shares \\
\hline & Return on Equity & (Net profit / equity) * 100 \\
\hline & Return on Assets & (Net profit / total assets) ${ }^{*} 100$ \\
\hline \multirow[t]{2}{*}{ Activity ratios } & Investment deposits & (Investments / deposits) * 100 \\
\hline & Employment of resources & $($ Investments / (deposits + Equity) $) * 100$ \\
\hline \multirow{3}{*}{$\begin{array}{l}\text { Debt } \\
\text { Management }\end{array}$} & Liabilities to assets & Liabilities / assets \\
\hline & Liabilities to Equity & Liabilities / equity \\
\hline & Equity multiplier & Assets / equity \\
\hline \multirow[t]{2}{*}{ Market rates } & Market value to book value & (Market value per share / book value) * 100 \\
\hline & Earnings per share to the market value & $\begin{array}{l}\text { (Earnings per share / market value of the shares) * } \\
100\end{array}$ \\
\hline
\end{tabular}

\section{Financial analysis using financial ratios:}

The researchers chose financial ratios to include all aspects of the performance of the bank, which consists of five groups: liquidity ratios, and profitability ratios, activity ratios, debt management ratios, and proportions of the market, as been shown in the following table: 
First, liquidity ratios: Liquidity is in an index of the bank's ability to meet financial obligations in an effective and suitable timing.

\section{(p.39. 2010, Mabwe and Rober)}

a. Current ratio: The researchers have studied this ratio because it is an indicator to the margin of safety through the ability of current assets in the bank to cover current liabilities (Naimi and Al-Tamimi, 2008, p 90). It is noted that and notes from the results shown in Table (2) that the average proportion of trading for the bank in the Islamic banking system was ( $74.88 \%)$, which is higher than the average in the banking system $(71.47 \%)$. This means that the ability of the bank in the period of the Islamic banking system to meet its current assets versus current without the need to break the deposit futures higher than his ability on it in the conventional banking system. It is also notable that the standard deviation of the gravity low trading average as measured by the standard deviation of the bank in the period of the Islamic banking system (0.066) which is less than the period of the conventional banking system (0.089). The coefficient of variation of the ratio of trading for the bank in the period of the Islamic banking system was (0.089) which is less than the period of the conventional banking system (0.13), and perhaps this indicates a decline in the seriousness of the inability of the bank to meet its ongoing obligation Under the new banking system compared to his ability in the banking system prior to the fulfillment of them. We shall not, here, overlook the signal for the consequences of the global financial crisis in 2008 and its impact on the performance of banks in general and the impact on the financial indicators. It is a period in which the banks have headed to strengthen their traded assets under the unstable financial situation in order to provide coverage for the corresponding obligations of traded assets.

Table (2) Comparing the circulation ratio of Kuwait International Bank during the period of the two systems (2003 -2011)

\begin{tabular}{|l|l|l|l|}
\hline $\begin{array}{l}\text { Year } \\
(2003-2006)\end{array}$ & $\begin{array}{l}\text { Kuwait Real Estate } \\
\text { Bank } \\
\text { (Conventional System) }\end{array}$ & $\begin{array}{l}\text { Year } \\
(2008-2011)\end{array}$ & $\begin{array}{l}\text { Kuwait International Bank } \\
\text { (Islamic Bank System) }\end{array}$ \\
\hline Average & $71.47 \%$ & Average & $74.88 \%$ \\
\hline Difference coefficient & 0.13 & Difference coefficient & 0.089 \\
\hline
\end{tabular}

B - Rapid liquidity ratio The two researchers have studied this ratio. It is equal to the circulation ratio because it includes the long - term investments as assets that can be liquefied rapidly. Therefore, this ratio is used as very strong standards in measuring the company's ability to cover its short - term liabilities. Thus, the fiscal analysts are looking forward rapid liquidity estimate ed at 1:1 as an acceptable goal for this ratio (Fahami Mustafa Al Sheikh, 2008, P 33) . According to the results shown in the table no (3), it noticed that the average ratio of the rapid liquidity for the bank in the Islamic Banking System period was (14.65\%). It is more than the average in the Conventional Banking System period (1.98\%). This means ability of the bank to fulfill its liabilities in the emergent conditions with no need to break its delayed deposits in the Islamic Banking System period is more than its ability to do that in the conventional banking system period. It is noticed, in return, from standard deviation that the risk of the decrease of the rapid liquidity ratio than the average measured by the standard deviation of the bank in the Islamic Banking System period (0.095) is more than the Conventional Banking System period (0.011). The difference coefficient of the rapid liquidity ratio in the Islamic Banking System period (0.65) is more than the Conventional Banking System period (0.55).

Table (3) Comparing the rapid liquidity ratio of Kuwait International Bank during the period of the two systems (2003-2011)

\begin{tabular}{|l|l|l|l|}
\hline $\begin{array}{l}\text { Year } \\
(2003-2006)\end{array}$ & $\begin{array}{l}\text { Kuwait Real Estate } \\
\text { Bank } \\
(\text { Conventional System) }\end{array}$ & $\begin{array}{l}\text { Year } \\
(2008-2011)\end{array}$ & $\begin{array}{l}\text { Kuwait International Bank } \\
\text { (Islamic Bank System) }\end{array}$ \\
\hline Average & $1.98 \%$ & Average & $14.65 \%$ \\
\hline Standard deviation & 0.011 & Standard deviation & 0.095 \\
\hline Difference coefficient & 0.55 & Difference coefficient & 0.65 \\
\hline
\end{tabular}

Second : Profitability ratio The profitability is considered as a very important tool to measure the efficiency of the administration in using its resources efficiently. The profitability can be measured through the following standards: ( Fahmi Mustafa 2008, p 47).

A - Book value of share The two researchers have studied the book value of the bank's share to know the growth that has been achieved in the rights of the shareholders (Mohamed Mater, $2006, \mathrm{P} 269$ ). According to the table (4), it is noticed that the average of the book value of Kuwait International Bank during the period (2008-2011), the Islamic Banking 
System period, reached (203.027) and it was less in the period (2003-2006) , the previous system period, to be estimated at (227.539), the matter indicating that the growth of the profitability in the Islamic Banking System period which is evaluated by the book value of the share here is less than the amount of growth in the bank profitability in the Conventional system period. This, actually, indicates better performance for the bank in comparison with the book value in the previous banking system. In return, the risk of the decrease in this ratio than the average in the Islamic Banking System period which is evaluated by the standard deviation reached (16.422). It is less than the Conventional Banking System period (38.161). The difference coefficient has indicated distracting ratio less than the Islamic Banking System period (0.081) if compared by the Conventional Banking System period (0.168).

Table no. (4) Comparing the book value of Kuwait International Bank during the period of the two systems (2003-2011)

\begin{tabular}{|l|l|l|l|}
\hline $\begin{array}{l}\text { Year } \\
(2003-2006)\end{array}$ & $\begin{array}{l}\text { Kuwait Real Estate } \\
\text { Bank } \\
\text { (Conventional System) }\end{array}$ & $\begin{array}{l}\text { Year } \\
(\text { 2008-2011) }\end{array}$ & $\begin{array}{l}\text { Kuwait International Bank } \\
\text { (Islamic Bank System) }\end{array}$ \\
\hline Average & 227.539 & Average & 203.027 \\
\hline Standard deviation & 38.161 & Standard deviation & 16.422 \\
\hline Difference coefficient & 0.168 & Difference coefficient & 0.081 \\
\hline
\end{tabular}

B - Share return As for the share return can be measured by the profits available for holders of normal shares. It is also indicates the possible growth in the equity which is reflected, in its turn, on the marketing prices for the shares to achieve the capital profits. Therefore, the administration tries to enlarge the profitability of the share due to the positive effect it has on enlarging the wealth of the long - term shareholders (Al Noeimi and Al Tamimi, 2008, P 4). According to the table no. (5), It is noticed that the average return of the share for the bank in the Conventional Banking System period (24.918) was bigger than the Islamic System Period (11.015). As we mentioned above, the increase in the capital in 2004 has affected positively on the share return due to the increase of the bank's capital throughout the year. The risk of the decreased of the share return than the average for the bank in the Islamic Banking System period (14.06) was near to the pervious Banking System period (14.24) with increase in the pervious system period. As for the difference coefficient, it indicates that the distracting ratio of the bank's share return in the Islamic System period (1.28) was higher than in the Conventional Banking System period (0.75)

Table no. (5) Comparing the share return of Kuwait International Bank during the period of both systems ( 20032011)

\begin{tabular}{|l|l|l|c|}
\hline Year & $\begin{array}{l}\text { Kuwait Real Estate } \\
\text { Bank } \\
\text { (2003-2006) } \\
\text { System) }\end{array}$ & $\begin{array}{l}\text { Year } \\
(2008-2011)\end{array}$ & $\begin{array}{c}\text { Kuwait International Bank } \\
\text { (Islamic Bank System) }\end{array}$ \\
\hline Average & 24.918 & Average & 11.015 \\
\hline Standard deviation & 14.24 & Standard deviation & 14.06 \\
\hline Difference coefficient & 0.75 & Difference coefficient & 1.28 \\
\hline
\end{tabular}

C - Equity Return Ratio :It measures the amount of the profit achieved as a ratio of the equity, and thus the net profit average which achieved by the investors from investing their monies as a return for their risks in employing their monies . This ratio indicates the efficiency of the administration in employing the monies of the investors ( Fahmi Mustafa Al Sheikh, 2008, P 47). According to the table no (6), comparison of the equity return ratio, it is noticed that the equity return average is increased in the previous banking system (10.46\%) more than the new banking system (5.26\%). As for the risk of this ratio decrease than the average (0.072) for the bank in the new banking system period, it is higher than the previous banking system period $(0.047)$. It is also noticed that the difference coefficient was higher than the new banking system period (1.37) in the period of the previous banking system (0.45), the matter indicating that the decrease in the profitability ratio comparing with the equity return ratio is less for the bank than the previous Banking System period than the new system.

Table no. (6)

\begin{tabular}{|l|l|l|l|}
\hline $\begin{array}{l}\text { Year } \\
(2003-2006)\end{array}$ & $\begin{array}{l}\text { Kuwait Real Estate Bank } \\
(\text { Conventional System })\end{array}$ & $\begin{array}{l}\text { Year } \\
(2008-2011)\end{array}$ & $\begin{array}{l}\text { Kuwait International Bank } \\
\text { (Islamic Bank System) }\end{array}$ \\
\hline Average & $10.46 \%$ & Average & $5.26 \%$ \\
\hline Standard deviation & 0.047 & Standard deviation & 0.072 \\
\hline Difference coefficient & 0.45 & Difference coefficient & 1.37 \\
\hline
\end{tabular}


D - Assets Return Ratio It measures the ratio of the assets returns, the productivity of the Kuwaiti Dinar invested in the assets. The higher is this ratio, the better is the profitability of the bank, indicating the correct investment decisions which were taken by the bank administration. Based on the table no. (7), it found that the ratio of the assets return for the bank in the specialized Conventional Banking System period (2.07\%) was higher than the comprehensive Islamic Banking System period $(0.89 \%)$. This difference can be interpreted as a difference of return between both banking systems. The risk of this ratio decrease than the average for the bank in the Islamic Banking System period $(0.011)$ is higher than the Conventional Banking System period (0.10). As for the difference coefficient, it was higher for the bank in the new banking system period (1.27) compared with (0.48) for the bank in the conventional banking system period, the matter indicating the risk of decrease is higher for the bank's profitability in the new banking system that can be measured by this ratio.

Table no. 7) Assets Return Ratio

\begin{tabular}{|l|l|l|l|}
\hline $\begin{array}{l}\text { Year } \\
(2003-2006)\end{array}$ & $\begin{array}{l}\text { Kuwait Real Estate Bank } \\
(\text { Conventional System })\end{array}$ & $\begin{array}{l}\text { Year } \\
(2008-2011)\end{array}$ & $\begin{array}{l}\text { Kuwait International Bank } \\
\text { (Islamic Bank System) }\end{array}$ \\
\hline Average & $2.07 \%$ & Average & $0.89 \%$ \\
\hline Standard deviation & 0.10 & Standard deviation & 0.89 \\
\hline Difference coefficient & 0.48 & Difference coefficient & 1.27 \\
\hline
\end{tabular}

Third : Activity ratios These indicators measure to what extent the bank is able to employee the monies collected from the deposits. The higher is the value of these ratios, the more positive is the indicator of the bank in making use of its resources.

Deposits Investment Ratio The two researchers have studied the measurement of the invested deposits ratio. As this ratio is increased, it indicates better operation efficiency for the investments, thus better performance. Based on the table no. (8), it's found that the average of this ratio for the bank in the period of the Islamic Bank System period estimated at $(12.64 \%)$ was less than the bank's ratio in the Conventional Banking System period estimated at $(28.83 \%)$. This indicates that the bank in the new banking system can invest the available deposits with a ratio less than the investment ratio in the previous banking system period. This may explain the reason behind the increase of the rapid liquidity in the bank in the Islamic Banking System period, in addition to the risk of this ratio decrease than the average (0.034). The difference coefficient in the new banking system period is less (0.27) if compared with the previous banking system period $(0.49)$.

Table no (8) Comparing deposits investment ratios of Kuwait International Bank during both systems (2003-2011)

\begin{tabular}{|l|l|l|l|}
\hline $\begin{array}{l}\text { Year } \\
(2003-2006)\end{array}$ & $\begin{array}{l}\text { Kuwait Real Estate Bank } \\
(\text { Conventional System })\end{array}$ & $\begin{array}{l}\text { Year } \\
(2008-2011)\end{array}$ & $\begin{array}{l}\text { Kuwait International Bank } \\
\text { (Islamic Bank System) }\end{array}$ \\
\hline Average & $28.83 \%$ & Average & $12.64 \%$ \\
\hline Standard deviation & 0.14 & Standard deviation & 0.034 \\
\hline Difference coefficient & 0.49 & Difference coefficient & 0.27 \\
\hline
\end{tabular}

B - Resources Employment Ratio :Resources Employment Ratio expresses to what extent the bank is able to employee its resources. The higher the ratio is, the better the performance is. The resources include the bank deposits, in addition to the equity (Al Momeni Et-al , 2005 - p 134). In the light of the table no (90), it is found that the resources employment ratio average is less for the bank in the Islamic Banking System period than the ratio average of the bank in the Conventional Banking System period, since it reached, in the light of the new banking system, $(9.92 \%)$. However it reaches, in light of the previous banking system, $(22.70 \%)$, indicating that the average employment of the bank's resources in the light of new system is less if compared with the previous system period. It is worth mentioning that the researcher has found that the bank, during the new system period, was interesting in providing the liquidity due to the consequences of the international financial crisis 2008 which made the fiscal sectors keep the liquidity during this period as a compensation for entering in new investments, in addition to the decrease of the investment ratio in this period because of the financial crisis.

The difference coefficient was smaller for the bank in the Islamic Banking System period (0.25) than in the previous banking system (0.49), the matter indicating that the risk of bank's investment in the light of the new banking system for its deposits is less than the risk of the bank's investment in the light of the previous banking system for its deposits.

Table no.(9) Comparing Resources Employment Ratio for Kuwait International Bank during Both Systems (2003-2011)

\begin{tabular}{|l|l|l|l|}
\hline $\begin{array}{l}\text { Year } \\
(2003-2006)\end{array}$ & $\begin{array}{l}\text { Kuwait Real Estate Bank } \\
(\text { Conventional System) }\end{array}$ & $\begin{array}{l}\text { Year } \\
(2008-2011)\end{array}$ & $\begin{array}{l}\text { Kuwait International Bank } \\
\text { (Islamic Bank System) }\end{array}$ \\
\hline Average & $22.7 \%$ & Average & $9.92 \%$ \\
\hline Standard deviation & 0.11 & Standard deviation & 0.025 \\
\hline
\end{tabular}




\begin{tabular}{|l|l|l|l|}
\hline Difference coefficient & 0.49 & Difference coefficient & 0.25 \\
\hline
\end{tabular}

Fourth: Debts Management Ratios This ratio aims at measuring to what extent the bank uses financial increase and avoids the long - term financial crisis. These ratios are also called the long - term filling ratios.

This ratio was studied by the two researchers to measure the ratio of the financial increase ratio because this increase indicates the increase of the financial risks for the bank. Based on the table no (10), it found that the average ratio in the Conventional Banking System period (80.31\%) is less than the Islamic Banking System period (83.46\%). Namely , the financial risks facing the bank is relatively high during the new system period . we have to mention here the effect that the international crisis in 2008 has on the performance of the banking sector generally and its negative consequences on the investments, leading to decreasing the value of the assets, particularly in the evaluations of the real estate market during this period, since the bank has focused its investments on the real estate from its yield of previous allocation in the real estate banking sector.

The risk of decrease in this ratio than the bank's average in the new banking system period $(0.016)$ is less than the previous period (0.022). As for the difference coefficient, it was higher for the bank in the Conventional Banking System period (0.027) than in the Islamic Banking System period (0.02). This means that the risk of decrease in the bank's assets in the Islamic Banking System period is less than the Conventional Banking System period.

Table no. (10) Comparing ratio of liabilities to assets for Kuwait International Bank during the period of both systems (2003-2011)

\begin{tabular}{|l|l|l|l|}
\hline $\begin{array}{l}\text { Year } \\
(2003-2006)\end{array}$ & $\begin{array}{l}\text { Kuwait Real Estate Bank } \\
(\text { Conventional System) }\end{array}$ & $\begin{array}{l}\text { Year } \\
(2008-2011)\end{array}$ & $\begin{array}{l}\text { Kuwait International Bank } \\
\text { (Islamic Bank System) }\end{array}$ \\
\hline Average & $80.31 \%$ & Average & $83.46 \%$ \\
\hline Standard deviation & 0.022 & Standard deviation & 0.016 \\
\hline Difference coefficient & 0.027 & Difference coefficient & 0.02 \\
\hline
\end{tabular}

B - Ratio of assets to equity The two researchers have studied this ratio to measure the amount of the risk faced by the bank due to depending on financing the current and capital activities from the long and short - term loans and liabilities (2009, P.260Charles H. Gibson).Based on the table no (5.09), the matter indicating that the bank was more able to face its commitments toward the equity in the previous system period than in the new system period This is reflected from the bank's capital increase through the Conventional System period which has increased the equity value comparing with the liabilities.

Table no. (11) Comparing the ratio of liabilities to the equity of Kuwait International Bank during the period of both systems (2003-2011)

\begin{tabular}{|l|l|l|l|}
\hline $\begin{array}{l}\text { Year } \\
(2003-2006)\end{array}$ & $\begin{array}{l}\text { Kuwait Real Estate Bank } \\
(\text { Conventional System) }\end{array}$ & $\begin{array}{l}\text { Year } \\
(2008-2011)\end{array}$ & $\begin{array}{l}\text { Kuwait International Bank } \\
\text { (Islamic Bank System) }\end{array}$ \\
\hline Average & 4.13 & Average & 5.09 \\
\hline Standard deviation & 0.57 & Standard deviation & 0.59 \\
\hline Difference coefficient & 0.14 & Difference coefficient & 0.12 \\
\hline
\end{tabular}

The risk of this ratio decrease than the bank's average in the Islamic Banking System (0.59) is higher than the Conventional Banking System (0.57). The difference coefficient in Islamic Banking System period (0.12) is less than the Conventional Banking System period (0.14), the matter indicating that the risk of decreasing the financial increase measured by this ratio was less for the bank in the Islamic Banking System period than the risk of decrease for the bank in the Conventional Banking System period.

Multiplying the equity :This ratio shows to what extent the bank can use the debts to finance its assets. In the light of the table no (12), It is noticed that multiplying the equity was less for the bank in the previous system period (5.13) than the new system period (6.09), the matter showing that the bank's ability to fulfill its commitments in the previous system is higher than its ability in the new system period. As we have mentioned previously, the increase of the bank's capital has contributed in this ability during the aforementioned period.

Table No.(12)Comparing multiplying equity for Kuwait International Bank during the period of both systems (2003-2011)

\begin{tabular}{|l|l|l|l|}
\hline $\begin{array}{l}\text { Year } \\
(2003-2006)\end{array}$ & $\begin{array}{l}\text { Kuwait Real Estate Bank } \\
(\text { Conventional System })\end{array}$ & $\begin{array}{l}\text { Year } \\
(2008-2011)\end{array}$ & $\begin{array}{l}\text { Kuwait International Bank } \\
\text { (Islamic Bank System) }\end{array}$ \\
\hline Average & 5.13 & Average & 6.09 \\
\hline Standard deviation & 0.57 & Standard deviation & 0.59 \\
\hline
\end{tabular}




\begin{tabular}{|l|l|l|l|}
\hline Difference coefficient & 0.11 & Difference coefficient & 0.097 \\
\hline
\end{tabular}

The risk of this ratio decrease than the bank's average in the Islamic Banking System period (0.59) is higher than the risk of the bank in the previous system (0.57). The difference coefficient for the bank in the Islamic Banking System (0.097) is less than the Conventional Banking System period (0.11).

\section{Fifth : Market Ratios}

The two researchers show that the market ratios are related closely to the share market value, share price value comparing with the book value taken from the banks' financial lists to measure the effect that the bank has on the normal shares prices in the market.

Ratio of the market value to the book value :the two researchers have conducted their study to know the situations of the bank and evaluate it on the part of the investors in the financial market ( Fahmi Mustafa , 2008, p 17), kindly informed that the average of this ratio is more than 1 for both systems. However, it is bigger in the Conventional Banking System period (2.944) than the Islamic Banking System period (1.254) as it is shown in the table no (13). This means that the chances of improvement and development of the value performance for both systems are available. However, these chances were bigger for the bank in the previous banking system period than the new banking system period. Here, we should mention the effect that the international financial crisis in 2008 has on the performance of the international stock markets generally which, in its return, has a negative effect on the performance of the exchange markets to be reflected on the market value for the included shares.

The risk of this ratio decrease than the bank's average in the Islamic Banking System (0.270) is less than the Conventional Banking System period (0.8). As for the difference coefficient, it was higher for the bank in the Conventional Banking System period ( 0.27) than in the Islamic Banking System (0.216). This matter indicates that the risk of the decreasing the bank's performance in the Islamic Banking System period in the stock market measured by this ratio is less than its risk for the bank in the Conventional Banking System period.

Table no . (13) Comparing the ratio of the market value to the book value for Kuwait International Bank during the period of both systems (2003-2011).

\begin{tabular}{|l|l|l|l|}
\hline $\begin{array}{l}\text { Year } \\
(2003-2006)\end{array}$ & $\begin{array}{l}\text { Kuwait Real Estate Bank } \\
(\text { Conventional System })\end{array}$ & $\begin{array}{l}\text { Year } \\
(2008-2011)\end{array}$ & $\begin{array}{l}\text { Kuwait International Bank } \\
\text { (Islamic Bank System) }\end{array}$ \\
\hline Average & $2.944 \%$ & Average & $1.254 \%$ \\
\hline Standard deviation & 0.8 & Standard deviation & 0.270 \\
\hline Difference coefficient & 0.27 & Difference coefficient & 0.216 \\
\hline
\end{tabular}

\section{Ratio of share return to the market value}

The two researchers have conducted their study to know to what extent the share is strong in the stock market which increase indicates that the bank's performance in the market is better (Mohamed Matter, 2006, P 268) . According to the table no(14), it is found that the average of share return to the market value of the share was higher for the bank in the Conventional System period $(4.1471 \%)$ than in the Islamic System period $(3.8496 \%)$, the matter which indicates that the performance of the share in the previous banking system period is better than the performance in the new banking system period. As we have shown above, however, the share is affected by negative external factors, namely, the international financial crisis in 2008 which has affected the exchange stock generally, leading to decreasing the average during the new banking system period, the target of the study.

Table no. (14) Comparing the ratio of the share return to the market value for Kuwait International Bank during the period of both systems (2003-2012)

\begin{tabular}{|l|l|l|l|}
\hline $\begin{array}{l}\text { Year } \\
(2003-2006)\end{array}$ & $\begin{array}{l}\text { Kuwait Real Estate Bank } \\
\text { (Conventional System) }\end{array}$ & $\begin{array}{l}\text { Year } \\
(2008-2011)\end{array}$ & $\begin{array}{l}\text { Kuwait International Bank } \\
\text { (Islamic Bank System) }\end{array}$ \\
\hline Average & $4.1471 \%$ & Average & $3.8496 \%$ \\
\hline Standard deviation & 2.63 & Standard deviation & 6.358 \\
\hline Difference coefficient & 0.63 & Difference coefficient & 1.651 \\
\hline
\end{tabular}

The risk of this ratio decrease than the bank's average in the Islamic Banking System period (6.358) is higher than in the Conventional Banking System (2.63). The difference coefficient in the Islamic Banking System period (1.651) is higher than in the Conventional Banking period (0.63).

\section{CONCLUSIONS AND RECOMMENDATIONS}

\section{Conclusions}


1. Previously well - done preparation and planning for the work plan of the banking system change and preparing the staff in the bank for the new stage are considered as one of the most important factors of successful process and its application.

2. The possibility of changing the conventional banks in the state of Kuwait to Islamic banks is available and legalized by special instructions issued by the Central Bank of Kuwait in a way that organizes the process and shows the required measures.

3. The bank, in the light of Islamic Banking System, can conduct highly - efficient activities to increase operating the deposits and move them toward better investments or the credited facilities, which leading to the ideal exploitation of the monetary liquidity. Therefore, the bank can achieve better performance which is reflected on the profitability.

4. The bank is expected, in the light of the Islamic Banking System, to achieve growth in the profits after the banking sector restores the financial stability situation and get rid of consequences of the international financial crisis 2008. This was shown through the values of the financial indicators for the consequent fiscal years, the matter indicating to the possibility of its continuity and success in the future if the bank seeks for achieving this goal.

5. Although the bank's share is decreased under the Islamic Banking System in the stock market, it is considered as an indicator built on an international reality that has an effect on all the shares included in the market. It is not considered as an individual performance indicator for the banks.

6. The financial ratios are considered as main indicators to identify the performance of the bank. Thus, internal and external factors facing the bank are taken into consideration to explain the different performance of the financial ratios in the period, the subject of study.

\section{Recommendations}

1. The bank should focus on the importance of its effective involvement in the banking sector and attempt to activate this involvement to resist those who doubt its performance under the Islamic Banking System comparing with its performance under the Conventional Banking System.

2. The necessity of improvement and development in the services and products of the bank which, in their turn, are reflected on renewing the customers' confidence and increasing their loyalty to deal with the bank, not with any other banks.

3. Assuring the principle of work according to the Islamic legal provisions in the bank which includes all the banking transactions to prevent any confusion in dealing with the customers and investors.

4. Finding the legal alternatives suitable for the most banking transactions and contracts to achieve the profits with developing and updating them in a way that meets the need of the market occasionally.

5. The Academic and educational institutions have to participate in the process of qualifying and trading the human cadres to be able to execute the requirements of the Islamic Banking work.

6. The researcher recommend to conduct a consequent study in a period when the banking sector is somewhat stable away from the financial crisis and its consequences to evaluate the bank's performance clearly without any negative external effect.

\section{REFERENCES}

[1] Hanafi, Abdul Ghaffar (2002), Banks Management, Al Nader University New House, Alexandria.

[2] Sheikh Fahmi Mustafa (2008), Financial Analysis, Edition 1, Palestine.

[3] Kuwait International Bank (2009), change, career and achievement, Kuwait.

[4] Matter, Mohamed (2006), Investments Management, The Theoretical Framework and Practical Applications , Edition 4, Wael House for Publication and Distribution, Jordan.

[5] Al Naeimi , Dr. Adnan and Dr. Rashed Al Tamimi (2008), Financial Planning and Analysis , Contemporary Orientations, Al Yazourdi House, Jordan.

[6] Annual Report for the Fiscal Data of Kuwait International Bank for the fiscal year 2008 (2009), Kuwait International Bank, Kuwait.

[7] Annual Report for the Fiscal Data of Kuwait International Bank for the fiscal year 2009 (2010), Kuwait International Bank, Kuwait.

[8] Annual Report for the Fiscal Data of Kuwait International Bank for the fiscal year 2010 (2011), Kuwait International Bank, Kuwait.

[9] Annual Report for the Fiscal Data of Kuwait International Bank for the fiscal year 2011 (2012), Kuwait International Bank, Kuwait.

[10] Annual Report for the Fiscal Data of Kuwait Real Estate Bank for the fiscal year 2006 (2007), Kuwait Real Estate Bank, Kuwait.

[11] Annual Report for the Fiscal Data of Kuwait Real Estate Bank for the fiscal year 2005 (2006), Kuwait Real Estate Bank, Kuwait

[12] Annual Report for the Fiscal Data of Kuwait Real Estate Bank for the fiscal year 2004 (2005), Kuwait Real Estate Bank, Kuwait

[13] Annual Report for the Fiscal Data of Kuwait Real Estate Bank for the fiscal year 2003 (2004), Kuwait Real Estate Bank, Kuwait

[14] Fiscal Report 2003-2006 (2006), Banking Studies Institute, Kuwait.

[15] Fiscal Report 2008-2011 (2012), Banking Studies Institute, Kuwait.

[16] Al Shareif , Fahad (2005), Islamic Branches Affiliating to the Conventional Banks, Research Paper submitted to the $3^{\text {rd }}$ International Conference for Islamic Economy, Om AIQorah University, Makah. 
[17] Safer, Ahmed (2004), Islamic Banking Work, Its Origins, Formulas, Challenges, Arab Banks Union, Beirut.

[18] Al Murtan, Saeid Bin Sad (2005), Islamic Branches and Outlets in the Conventional Banks - Experiment of Al Ahly Commercial Bank, Contemporary Islamic Economical Applications, Edited By Othman Baker Ahmed . Islamic Bank For Development, Institute of Researches and Training, Jeddah, First Edition.

[19] Al Attayat, Yazen Khalaf (2007), Change of Conventional Banks to work according to Islamic legal provisions , study to show the possibility of application in Jordan , Doctorate Thesis , Arab Academy For Financial and Banking Sciences.

[20] Al Shaarani, Ola Osamah (2010), The importance of applying the cost system according to the profitability activity in the Islamic banks, Master Thesis, Damascus University.

[21] Al Momeni , Dr. Monzer and Anan Al Sorogi (2005), comparing the performance of the Islamic and Conventional banks by using the financial ratios, Al Mannarah Magazine, Volume (13), Edition (2).

\section{Second : English Sources}

[1] Charles H. Gibson, Financial Reporting \& Analysis, $11^{\text {th }}$ edition. 2009, USA

[2] Mabwe Kumbirai and Robert Webb (2010). Financial Ratio Analysis of Commercial Bank Performance in South Africa. African Review of Economics and Finance, Vol. 2, No. 1, Dec 2010. 